\title{
COMMENTARY
}

\section{Pursuing Excellence in Your Academic Journey}

Gayle A. Brazeau, $\mathrm{PhD}^{\mathrm{a}, \mathrm{b}}$

${ }^{\text {a }}$ Editor, American Journal of Pharmaceutical Education, Arlington, Virginia

${ }^{\mathrm{b}}$ Marshall University, School of Pharmacy, Huntington, West Virginia

Corresponding Author: Gayle A. Brazeau, Marshall University, School of Pharmacy, One John Marshall Dr., Huntington, WV 25755. Tel: 304-696-7390. Email: brazeau@ marshall.edu

Submitted January 14, 2022; accepted January 15, 2022; ePublished January 2022

An academic career affords one the opportunity for continuous learning and professional growth in the course of the ups and downs and during good and bad times. A key element necessary to navigate one's academic career is to always focus on excellence as the core principle underlying our activities and interactions with others along the journey. The commentary reflects on four essential elements of excellence that can enhance one's academic journey. We should always care more, risk more, dream more and expect more than others think is possible as we approach the days and years of our academic careers.

Keywords: excellence, students, pharmacy, academic, career 
No one navigates their academic journey alone. The advantage of being a pharmacy educator is the opportunity to engage in our specific academy. An academy is defined as either a where individuals pursue study or training in a special field or a group of distinguished scholars or scientists that aims to promote and maintain the standards in its particular field. ${ }^{1}$ Our pharmacy academy is certainly a committed, dedicated group of faculty and staff members. Furthermore, we all have also benefited from our many mentors, colleagues and friends who have given generously of their time to guide us in our individual journey from that of a student, to a newly minted academician, through advancement in the academic ranks, and through leadership and administrative opportunities. Along our academic journey, we travel and develop lifelong friendships with our faculty colleagues, staff colleagues, residents, and post-doctoral fellows. The greatest advantage of any academic journey is that one can learn from individuals at our home institutions and from those we know in professional organizations and societies. Even with this ever-increasing opportunity to learn, no one can never truly predict where route for your academic journey. There will always be ups and downs in anyone's academic career. However, if your suitcase is packed with intellectual curiosity combined with a passion for learning, kindness, respect, enthusiasm, and gratitude, the journey will be one that is amazing and exciting.

Our lives, both personal and professional, have truly been transformed in some way or other by this COVID-19 experience. We have all grown and learned from our individual and collective experiences since that time. We should all take great pride in is the collective efforts of our students, alumni, preceptors, and faculty/staff members who stepped up without asking to contribute to the wide array of public health initiatives in our individual communities. Furthermore, we, as an academy, need to recognize the dedication that faculty/staff members demonstrated when transitioning to online learning thus ensuring continued education of future pharmacists in our colleges/schools. These times have most definitely been challenging for our pharmacy academy, but also in this period we have brightly shown what we offer through integrity, commitment, and resilience.

This will not necessarily be the end of the challenging times each of us may experience during our academic careers. It is these challenging times where we have learned the most about ourselves. A critical lesson that must be shared with other colleagues and students is that it does not matter how often you fall, the key is to always get back up and move forward to assist other individuals, organizations, and yourself toward excellence. Our individual and collective experiences must always be focused on excellence. This focus on excellence is best demonstrated through the words of Ronnie Oldham, specifically "Excellence is the result of caring more than others think is wise, risking more than others think is safe, dreaming more than others think is practical, and expecting more than others think is possible."

We, individually and collectively as pharmacy educators, can use these words as a strong framework to highlight why it is so critical to instill in our students, residents, colleagues, and friends the passion and drive towards excellence. In striving for excellence, we must first demonstrate caring more than others think is wise. All of us have benefited from those that have taught us the significance of caring for the others we teach, guide, and mentor. We care for others by listening, by questioning, by guiding, by teaching, by celebrating, by advising, and by learning. Often this caring seems risky, beyond what is generally considered wise because it requires us be vulnerable. Caring as a pharmacy educator and leader requires us to move beyond our comfort zone and be vulnerable to others, but in doing this we show our courage and conviction towards excellence. In Brené Brown's book "Daring Greatly: How the Courage to Be Vulnerable Transforms the Way We Live, Love, Parent, and Lead", she reminds us that vulnerability is the birthplace of love, belonging, joy, courage, and creativity. ${ }^{3}$ It is the source of hope, empathy, accountability, and authenticity. If we want greater clarity in our purpose or deeper or more meaningful spiritual lives, vulnerability is the path. ${ }^{3}$ Caring, and its key component vulnerability are the first essential components towards our goal for excellence.

Secondly to achieve excellence, we must be willing to is risk more than others may think is safe. Risking more means that we are willing to open to reframing our thinking, and more importantly, taking a leadership role in moving new ideas forward that may be initially uncomfortable to ourselves and to others. Pharmacy educators are bestowed with wonderful opportunity to investigate, explore, and learn about new knowledge, skills, and concepts in the biomedical, pharmaceutical, clinical, social-administrative sciences, and outside of conventional pharmacy education that come from our classrooms, laboratories, clinical practice sites, professional meetings and even the most mundane committee meetings. We potentially squander these opportunities when we are risk aversive to promoting and discussion new ideas because we and/or others believe it is not a safe pathway.

Secondly, risking more involves the commitment to assume leadership roles in our colleges/schools of pharmacy, when, the time is right for you and your career. Your leadership can be demonstrated at all levels from being an informed and active committee or task force member to a department chair, dean or beyond. Pharmacy education and practice will continue to need innovative, creative thinking individual who are willing to care and risk as leaders. Leading involves one's commitment to excellence, tough decision-making towards excellence, and the willingness to accept the risk that comes with challenging those resistant to the new ideas and changes needed to move towards excellence. 
Pharmacy and pharmacy education will continue to have challenges in the nature, scope, requirements, and expectations for what is needed for success. These challenges will only be solved when each of us are willing to take the risk in being open to new ideas and expecting more in what we achieve in our quest for excellence. We need to focus our efforts on educating pharmacists on what they can do with their knowledge and skill sets rather than the specific roles and places they will work. We need to inspire our students to be creative, innovative, and willing to take risks. It is our students and mentees, with our mentoring and guidance, who will assume the reigns to advance pharmacy and pharmacy education.

The third element in our quest for excellence is dreaming more than others think is practical. You might wonder why dreaming beyond what is practical is related to excellence. Simply put: our dreaming is about the ability to visualize something that does not exist but does have the possibility. All of us have dreams about our goals for our personal and professional life and what we believe this will look like? One needs to reflect on how they have achieved their goals and how are you working toward your future goals? Striving for professional excellence is living your passions each day.

The fourth element in our drive for excellence is expecting more than others think is possible. I have always believed that we need to demonstrate daily to others our dedication and commitment as an educator and mentor. What does it look like to be an educator and mentor that does more than others think is possible? We can gain great insight into this topic through the lessons in Ken Bain's 2004 book "What the Best College Teachers Do". Bain discusses six broad questions that we should consider as college teachers [an mentors]. Three of the six broad areas relate to expecting more than others think is possible. Specifically, the best college teachers treat teaching as a serious academic endeavor, they expect more from their students with a focus on the type of thinking and acting that will be expected for life, and they share their own intellectual curiosity and journey thus trying to instill in students the gravity of stimulating their own intellectual curiosity and being reflective in their life experiences. Successfully striving for these three requires time and dedication that exceeds what many others think is possible.

What is needed if you are expecting and doing more than others think is possible. Spencer Johnson's 2014 book "Peaks and Valleys: Making Good and Bad Times Work for You" provides a useful approach by suggesting that each of us need to have our "sensible vision". ${ }^{5}$ One's sensible vision is imaging yourself enjoying your better future in such specific, believable detail that soon you will be enjoying what it takes to get there. With one's sensible vision, you will soon be doing more than what others believe is possible. As educators and mentors, we need to share our sensible vision with each other, and more importantly, take the time to instill in our students how essential it is one to define their own sensible vision and work towards that vision framed with the goal of excellence.

In summary, my assumption is that one of the reasons many of us chose an academic pharmacy career was the potential to make a difference by teaching and mentoring others in their journey towards excellence as they become the next great generation of pharmacists, scientists, and academicians. All of us can remember a time when working with a student who was struggling and suddenly the understand the learning becomes internalized. Parker Palmer's 1998 book "The Courage to Teach: Exploring the Inner Landscape of a Teacher's Life" summarizes this in our teaching when he reminds us "I am a teacher at heart and there are moments in the classroom where I can hardly hold the joy. When my students and I discover uncharted territory to explore, when the pathway out of a thicket opens before us, when our experience is illuminated by the lightning-life of the mind - then teaching is the finest work I know." 6 This sentence embodies the entire spectrum of the joy in being an educator focusing on excellence. We start by caring more for our students. Secondly, we are willing to risk more because of our passion to enable student success. In addition, we focus on inspiring our students to dream more so that they can envision their success. Finally, we are always expecting more of our students as we enhance their foundation to think critically and innovatively.

Excellence must be our individual and collective mantra as pharmacy educators. The great coach Vince Lombardi summed it up well by saying, "A person's quality of life is in direct proportion of a person's commitment to excellence, regardless of what field they may be in."7 It is only as one strives towards their own personal commitment to excellence that will be the guarantee that your quality of life meets your greatest expectations.

\section{ACKNOWLEDGEMENT}

Dr. Brazeau was the recipient of the 2020 Robert K. Chalmers Distinguished Pharmacy Educator. 


\section{REFERENCES}

1. Google Definition of the word academy, https://www.google.com/search?client=firefox-b-1-

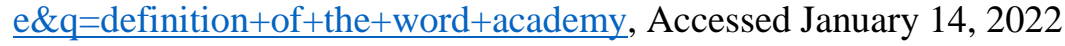

2. Goodreads Quotes, https://www.goodreads.com/quotes/236532-excellence-is-the-result-of-caring-more-thanothers-think, Accessed January 14, 2022.

3. Brown B. Daring Greatly: How the Courage to be Vulnerable Transforms the Way We Live, Love, Parent and Lead. London, England: Portfolio Penguin; 2013.

4. Bain K. What the best college teachers do. Cambridge, MA: Harvard University Press; 2004.

5. Johnson S. Peaks and valleys: making good and bad times work for you--at work and in life. New York, NY Atria Books; 2009.

6. Palmer PJ. The Courage to Teach Exploring the Inner Landscape of a Teacher's Life. San Francisco, CA: JosseyBass; 1998.

7. BrainyQuote, https://www.brainyquote.com/quotes/vince_lombardi_121318, Accessed January 14, 2022. 